\title{
WISATA EKSPLORASI AIR
}

\author{
Septiawan Perdana Putro ${ }^{1)}$, Eduard Tjahjadi ${ }^{2)}$ \\ 1) Program Studi S1 Arsitektur, Fakultas Teknik, Universitas Tarumanagara, septiawanp.ta@stu.untar.ac.id \\ ${ }^{2}$ Program Studi S1 Arsitektur, Fakultas Teknik, Universitas Tarumanagara, eduard.tjahjadi8@gmail.com
}

\begin{abstract}
Abstrak
Air merupakan kebutuhan utama bagi proses kehidupan di bumi, sehingga tidak ada kehidupan seandainya tidak ada air di bumi. Namun air dapat menjadi malapetaka jika tersedia dalam kondisi yang tidak baik dalam segi kualitas maupun kuantitas. Air yang bersih sangat dibutuhkan manusia, baik untuk keperluan sehari-hari, untuk keperluan industri, untuk kebersihan sanitasi kota, dan sebagainya.Di zaman sekarang air menjadi masalah yang memerlukan perhatian lebih serius. Untuk mendapatkan air yang baik sesuai dengan standar tertentu sudah cukup sulit untuk didapatkan. Hal ini dikarenakan air sudah tercemar oleh bermacam-macam limbah dari berbagai hasil kegiatan manusia. Makhlup hidup yang berada di air pun turut merasakan dampaknya mulai dari banyaknya ikan yang mati. Jakarta merupakan Ibu Kota Negara yang dijadikan sebagai pusat kegiatan pemerintahan, perdagangan dan perekonomian. Oleh karenanya Jakarta dikatakan sebagai kota metropolis. Kehidupan masyarakat di kota-kota besar seperti Jakarta menimbulkan berbagai dampak negatif terhadap jiwa (psikis) dan rohani (psikologis). Masyarakat di kota-kota besar sangat dipengaruhi oleh dinamika kota tersebut. Pengaruh tersebut membawa dampak di dalam setiap strata sosial masyarakat. Beban kehidupan kota metropolitan merupakan faktor penekan beban kehidupan seseorang yang pengaruhnya sangat dominan, baik secara ekonomi, sosial, budaya, atau pun keamanan. Tekanan kehidupan yang begitu dominan tersebut akan berimbas kepada tinggi rendahnya stres seseorang, yang pada akhirnya stres yang tinggi disebabkan karena beban kehidupan masyarakat metropolitan yang sangat berat.
\end{abstract}

Kata kunci: air, proses, masalah, stress

\begin{abstract}
Water is a major need for life processes on earth, so there is no life if there is no water on earth. But water can be disastrous if it is available in conditions that are not good in terms of quality or quantity. Clean water is needed by humans, both for daily needs, for industrial purposes, for sanitation of city sanitation, and so on.Nowadays water is a problem that needs more serious attention. To get good water in accordance with certain standards is quite difficult to obtain. This is because water has been polluted by various kinds of waste from various human activities. The morality of life in the water also contributes to the effects of the many dead fish.Jakarta is a State Capital that is used as the center of government activities, trade and economy, for which Jakarta is said to be a metropolis. The lives of people in big cities, such as Jakarta, have a variety of negative impacts on the soul (psychic) and spiritual (psychological). Communities in big cities will be greatly influenced by the dynamics of the city. The influence has an impact on every social strata of the community. The burden of metropolitan city life is a pressure factor on the life of someone whose influence is very dominant, both economically, socially, culturally, or even security. Such a dominant life pressure will affect a person's high
\end{abstract}

Keywords: process, problem, stress, water

\section{PENDAHULUAN}

Air merupakan kebutuhan utama bagi proses kehidupan di bumi, sehingga tidak ada kehidupan seandainya tidak ada air di bumi. Namun air dapat menjadi malapetaka jika tersedia dalam kondisi yang tidak baik dalam segi kualitas maupun kuantitas. Air yang bersih sangat 
dibutuhkan manusia, baik untuk keperluan sehari-hari, untuk keperluan industri, untuk kebersihan sanitasi kota, dan sebagainya.

Di zaman sekarang air menjadi masalah yang memerlukan perhatian lebih serius. Untuk mendapatkan air yang baik sesuai dengan standar tertentu sudah cukup sulit untuk didapatkan. Hal ini dikarenakan air sudah tercemar oleh bermacam-macam limbah dari berbagai hasil kegiatan manusia. Makhlup hidup yang berada di air pun turut merasakan dampaknya mulai dari banyaknya ikan yang mati.

Beban kehidupan kota metropolitan merupakan faktor penekan beban kehidupan seseorang yang pengaruhnya sangat dominan, baik secara ekonomi, sosial, budaya, atau pun keamanan. Tekanan kehidupan yang begitu dominan tersebut akan berimbas kepada tinggi rendahnya stres seseorang, yang pada akhirnya stres yang tinggi disebabkan karena beban kehidupan masyarakat metropolitan yang sangat berat.

Berdasarkan latar belakang diatas, dapat diidentifikasi bahwa terdapat masalah utama yang dihadapi kota metropolis, khususnya kota Jakarta, yaitu:

- Pencemaran air yang sudah parah karena kurangnya kesadaran dan pengetahuan masyarakat tentang pentingnya air bagi kehidupan, dan tingkat stress penduduk yang yang tinggi disebabkan kehidupan kota metropolis yang berat.

- Kurangnya ketertarikan masyarakat untuk datang ke tempat edukasi atau pusat informasi tentang pentingnya manfaat air bagi kehidupan sekarang maupun untuk masa yang akan datang.

- Kurang menarik untuk mencakup semua umur di jaman sekarang ini jika hanya menyediakan wisata yang mengandung edukasi tanpa ada program lainnya yang mendukung karena desain menggunakan pendekatan "fungsional". Ruang perkotaan atau kawasan sebagai suatu kesatuan dalam unit fungsi pada desain dan lokasi terpilih termasuk ke dalam kawasan yang tergolong kawasan yang mempunya kelas menengah bawah dan juga kumuh.

Gambar 1. Peta Kawasan Kumuh Sekitar Waduk Pluit Sumber: Olahan penulis, 2018

Tujuan dari proyek ini adalah menciptakan suatu perancangan fisik berupa Wisata eksplorasi air yang mengandung edukasi, yang dapat memberikan kesadaran masyarakat terhadap pentingnya dan manfaat dari air bersih dan juga membantu memenuhi kebutuhan masyarakat kota metropolis ditinjau dari pemenuhan kebutuhan ruang beserta dengan persyaratan teknis, keamanan, dan kenyamanan bagi pengguna bangunan. Selain itu juga menciptakan suatu bangunan yang menarik dan dapat menjadi suatu ikon yang ditinjau dari sisi arsitektural.

Proyek diharapkan dapat menjadi satu sarana atau wadah untuk memenuhi salah satu bagian kecil namun berdampak besar bagi masyarakat metropolis untuk menyadarkan pentingnya air bersih dan juga pemeliharaan kesehatan mental. Maka dengan demikian direncanakanlah sebuah fasilitas yaitu Wisata eksplorasi air. Dengan usulan proyek tersebut diharapkan masyarakat akan sadar pentingnya air bersih dan manfaatnya terhadap kebutuhan sehari hari untuk kehidupan dan juga bisa mengurangi dan pemperbaiki mental psikologis dari masyarakat metropolis yang stress. Dengan adanya program wisata eksplorasi air yang berasal dari olahan air kotor yang ada di sekitar tapak; bertujuan untuk memunculkan wisata berelemen air yang bermanfaat terhadap keluhan psikologis masyarakat kota metropolis dan juga dengan itu kesadaran masyarakat timbul dari program tersebut jika air bersih itu banyak manfaat dan kegunaannya agar masyarakat menjaganya dan juga program memanfaatkan kebutuhan air dari pengolahan air kotor yang lebih ramah lingkungan.

\section{KAJIAN LITERATUR}




\section{Pariwisata}

Menurut Kamus Besar Bahasa Indonesia, pengertian wisata adalah bepergian secara bersama-sama dengan tujuan untuk bersenang-senang, menambah pengetahuan, dan lainlain. Kegiatan wisata dilakukan bukan di rumah atau di kediaman si pelaku kegiatan melainkan di suatu tempat tujuan tertentu, sehingga kegiatan tersebut memerlukan proses perjalanan, baik menggunakan media (transportasi darat/laut/udara) maupun tidak.

Pariwisata (Tours): adalah perjalanan wisata yang dilakukan secara berkali-kali atau berkeliling-keliling, baik secara terencana maupun tidak terencana yang dapat menghasilkan pengalaman total bagi pelakunya. Dari pengertian tersebut terlihat bahwa kegiatan wisata merupakan bagian dari kegiatan pariwisata, karena kegiatan pariwisata merupakan kegiatan jamak dari kegiatan wisata itu sendiri.

Pariwisata merupakan sektor yang sangat strategis dalam meningkatkan pendapatan masyarakat dan negara terutama bila dikaitkan dengan peningkatan jumlah arus wisatawan. Selain itu pembangunan yang terus-menerus dalam sektor pariwisata ini akan mampu mangangkat sektor ekonomi lainnya seperti perhubungan, kehutanan, industri, pekerjaan umum dan lain sebagainya (Fandeli, 1995)

Perbedaan architectural tourism dengan tourism architecture adalah, architectural tourism lebih dirancang sebagai objek yang menjadi atraksi dan pusat pandangan para turis. Sedangkan, tourism architecture memiliki daya tarik dengan program-program yang diajukan.

\section{Kota Metropolis}

Secara etimologi (asal kata) kata metropolitan (kata benda) atau metropolis (kata sifat) berasal dari bahasa Yunani Kuno, yaitu kata meter yang berarti ibu dan kata polis yang berari kota. (Wackerman, 2000). Pada masa itu, metropolitan memiliki makna sebagai "kota ibu" yang memiliki kota-kota satelit sebagai anak, namun dapat juga berarti pusat dari sebuah kota, sebuah kota negara (city-state), atau sebuah propinsi di kawasan Mediterania (Winarso, 2006).

Definisi kawasan metropolitan yang relevan dalam konteks negara Indonesia, yaitu berdasarkan Undang-Undang No. 26 Tahun 2007 tentang Penataan Ruang. Undang-Undang tersebut mendefinisikan kawasan metropolitan sebagai kawasan perkotaan yang terdiri atas sebuah kawasan perkotaan yang berdiri sendiri atau kawasan perkotaan inti dengan kawasan perkotaan di sekitarnya yang saling memiliki keterkaitan fungsional yang dihubungkan dengan sistem jaringan prasarana wilayah yang terintegrasi dengan jumlah penduduk secara keseluruhan sekurang-kurangnya 1.000 .000 jiwa.

\section{Ekologi dan Ekowisata}

Ekologi adalah ilmu yang mempelajari interaksi antara organisme dengan lingkungannya dan yang lainnya. Berasal dari kata Yunani oikos ("habitat") dan logos ("ilmu"). Ekologi diartikan sebagai ilmu yang mempelajari baik interaksi antar makhluk hidup maupun interaksi antara makhluk hidup dan lingkungannya. Ekowisata dapat didefinisikan sebagai berpegian suatu daerah natural yang alamnya dikonservasi, ditopang oleh masyarakat lokal, dan melibatkan edukasi. Edukasi yang dimaksud melibatkan kedua pihak, baik itu pekerja atau pengunjung yang terdiri dari penjelasan, stimulasi, provokasi, dan inspirasi. Hubungan antara ekowisata dan edukasi berkatian dengan nilai- nilai pengelolaan lingkungan, budaya, dan sumber daya. Kunci keberhasilan dari sebuah ekowisata adalah untuk memperbaiki perilaku orang dan bertindak positif terhadap lingkungannya.

\section{Arsitektur dan Pariwisata di Kota Metropolis}

Sebagai salah satu bidang kehidupan masyarakat, arsitektur berpotensi besar untuk berperan dalam pengembangan pariwisata. Di samping berperan sebagai alat untuk mewujudkan lingkungan binaan yang menyenangkan untuk berwisata, arsitektur juga dapat dijadikan sebagai obyek wisata, hal ini disebut juga architectural tourism yang dengan kata lain 
adalah arsitektur yang dirancang untuk menjadi atraksi. Dengan kegiatan pariwisata atau program dari pariwisata itu sendiri, berbagai manfaat akan dapat diraih, sebab pada hakekatnya pembangunan pariwisata merupakan kesatuan upaya yang dilakukan oleh pemerintah, kalangan usaha dan masyarakat secara terkoordinir dan terpadu dalam rangka meningkatkan kunjungan wisata, hal ini disebut juga tourism architecture yang dengan kata lain berkaitan dengan program yang diajukan.

Pariwisata dalam ruang metropolis memiliki tuntutan besar, dimana harus mencerminkan keseimbangan antara architectural tourism dan tourism architecture. Dengan kata lain, program yang diusulkan harus bisa menarik wisatawan dan juga dari segi arsitektur juga bisa menjadi objek dari pariwisata itu sendiri. Architourism dapat menjadi titik tolak dari ruang metropolis di berbagai bidang. Sebuah bangunan yang memiliki nilai arsitektur yang tinggi dapat menandakan kemakmuran, kemajuan teknologi, dan bahkan tingkat sosial masyarakat sebuah metropolis. Terutama bangunan yang memiliki pengakuan dunia, hal ini dapat menempatkan kota metropolis tersebut naik ke jajaran negara-negara maju yang juga memiliki nilai tinggi dalam aspek architourism, sekaligus dapat mengangkat nilai budaya dan berbagai sektor dalam ruang metropolis itu sendiri.

Tidak dapat dipungkiri bahwa air sangat dibutuhkan oleh manusia sejak kelahiran, pertumbuhan, hingga kematiannya. Berbagai usaha penjernihan secara mekanis dilakukan orang, melalui filterisasi, sedimentasi, dsb. menyalurkannya lewat jaringan pipa-pipa air bawah tanah menuju kran di bangunan maupun taman. Orang begitu terbiasa, khususnya mereka yang tinggal di kota, untuk mendapatkan air bersih dengan hanya memutar kran, tanpa memikirkan dari mana asal air atau bagaimana selanjutnya perjalanan air di alam, atau bagaimana air juga dapat menjadi kekuatan yang merusak, menjadi bencana bagi kehidupan manusia.

Jelas terlihat di sini bahwa selain bermanfaat untuk memenuhi kebutuhan fisik manusia, air juga mempunyai makna akertaji (intangible) bagi kehidupan manusia. Desain arsitektur yang memasukkan komponen air, mengingatkan manusia akan dampak ganda tersebut bagi kehidupan manusia. Hal ini berarti kita tidak dapat mengabaikan peran sejarah dan simbolisasi dalam mempertahankan hubungan antara manusia dengan air, dengan alam dan dengan sesamanya. Untuk itu mempelajari masa lalu, mitos atau kepercayaan yang menunjukkan makna akertaji dari air sehingga dapat memberi pencerahan dalam menghadapi kompleksitas kehidupan.

\section{Sebagai Kepuasan Estetika}

Di sini terlihat air selain bernilai fungsional berperan pula sebagai pembentuk kepuasan estetika dan relaksasi. Keberadaan air sangat esensial, tidak hanya melayani kebutuhan arsitektural tetapi juga merupakan simbolisasi kehidupan masa kini. Air sebagai inti dari court diwujudkan dalam bentuk yang beraneka ragam, baik dalam jumlah maupun dalam karakternya; ketenangan permukaannya, sekaligus kedinamisannya seperti kolam, air mancur, irigasi, dan kanal sempit untuk mendapatkan nuansa yang berbeda sehingga dapat meningkatkan nilai hidup manusia.

Sebagai Simbolisasi Metafisik

Air juga dihadirkan sebagai simbolisasi metafisik, Air tidak dihadirkan sekedar sebagai hiburan, tetapi sebagai wadah bagi aneka kekayaan alam, sebagai tempat meditasi dimana dapat diperoleh suasana penuh kedamaian, berbeda dengan konsep taman klasikal Itali maupun Aristrokrat Perancis yang menghadirkan kemegahan dan kemewahan.

\section{Sebagai Pembangkit Efek Psikologis}

Yang paling mendasar dari fungsi abstrak air dalam desain komposisi arsitektur adalah tak hanya dihadirkan sebagai elemen estetika saja, yang hanya dapat dinikmati oleh mata, tetapi juga sebagai elemen yang dapat dirasakan oleh berbagai indera lain, dapat diraba dan 
dirasakan dinginnya yang mencekam, atau didengar gemericik bunyinya atau debur gelombangnya. Air juga dihadirkan untuk membangkitkan kontak emosional, dihayati secara psikologis. Suara aliran air dapat meningkatkan rasa lebih sejuk (efek psikologis) terhadap suhu yang panas di daerah panas-kering.

Ketika suara gemiricik percikan air atau suara pancuran air bertemu dengan cahaya dan hangatnya sinar matahari, maka akan tercipta suasana yang berkesan melankolis, hipnotis dan puitis. Karakter reflektif dari air yang bertemu dengan efek audiovisual gerakan air menawarkan media bagi arsitek untuk menciptakan energi dan ruang. Banyak orang dapat terbuai oleh fenomena ini. Disini air benar-benar dirasakan oleh segenap jiwa manusia tak hanya sekedar dilihat dari luar saja.

\section{DISKUSI DAN HASIL}

Pada proyek yang ingin di rancang ini akan menyediakan beberapa program yaitu di dalamnya ada program utama, program pendamping, dan program pendukung yang terdiri dari:

- Program utama

air, manfaat air, fungsi air dimasa sekarang dan akan datang, proses air dari sumber hingga ke masyarakat untuk siap di gunakan.

- Program pendamping air buatan yang di dirancang sedemikian rupa hingga menyerupai ekosistem air alami)

- Pertunjukan air Pertunjukan air indoor (penggabungan pertunjukan secara langsung dengan virtual). Pertunjukan air outdoor (penggabungan pertunjukan secara langsung dengan virtual)

- Program pendukung Cafe dan gift shop

\section{KESIMPULAN DAN SARAN}

Wisata eksplorasi air ini di hadirkan untuk menyadarkan masyarakat akan pentingnya air di masa sekarang dan dimasa yang akan datang. Melalui pendekatan desain katalis yang coba diterjemahkan pada proyek ini, penulis berupaya mengkaitkannya dengan arsitektur. Pendekatan katalis merupakan analogi dari cara kerja unsur katalisator dalam ilmu kimia. Penambahan suatu elemen yang baru dalam suatu kawasan akan menjadikan perubahan pada seluruh elemen kawasan. Perubahan yang terjadi dapat berupa perubahan pada kehidupan dan penghidupan masyarakat, bentuk, karakter, dan kualitas dari elemen-elemen suatu kawasan.

\section{UCAPAN TERIMA KASIH}

Penulis mengucapkan terima kasih kepada Tuhan Yang Maha Esa atas berkat dan karuniaNya, para Dosen yang telah membimbing, orang tua, teman-teman yang telah memberikan motivasi dan bantuannya, serta para narasumber sehingga penulis dapat menyelesaikan artikel jurnal Stupa ini.

\section{REFERENSI}

Hayllar, Bruce (ed) .(2008). City Spaces Tourist Places, Routledge

Maciocco,Giovanni and Serreli, Silvia. (2009). Enhancing the City: New Perspectives for Tourism and Leisure (Urban and Landscape Perspectives), Springer Dordrecht, Heidelberg London New York.

Specht, Jan. (2014). Architectural Tourism: Building for Urban Travel Destination, Springer Gabler, Germany 2

https://www.archdaily.com/339751/museum-of-nature-and-science-winning-proposalschwartzbesnosoff-so-architecture 
https://www.archdaily.com/314808/jerusalem-museum-of-nature-science-second-prizewinningproposal-mys-architects

http://www.aquatic-show.com/en/Water-and-lights-Screens-94.html http://coredesignstudio.com/laredo-water-museum/

https://www.ahhaa.ee/

https://www.archdaily.com/299603/water-treatment-plant-

awp/50b6da5eb3fc4b729400003fwater-treatment-plant-awp-photo

https://www.efteling.com/en/park/shows/aquanura

http://shubhamindia.com/grey-water-treatment-gwt/

https://www.hb-laser.com/images/references/10/holy_defense_museum_iran/Holy-

DefenseMuseum-Teheran-0005.jpg

https://joshua1993.wordpress.com/2010/01/29/megaplume-tornado-bawah-air/

https://www.researchgate.net/publication/239921095_Ecology_in_Architecture_Design_te

sting_a n_advanced_educational_path - $\quad$ http://www.saferain.com/en/fountain-

equipment.html 